\title{
Response of Low Birthweight Infants to Treatment with Folic Acid
}

\author{
W. L. BURLAND, K. SIMPSON, and JULIET LORD* \\ From the Clinical Investigation Unit, Glaxo Laboratories, Greenford, Middlesex; Paediatric Department, Leicester \\ General Hospital, and Department of Haematology, St. Bartholomew's Hospital, London
}

\begin{abstract}
Burland, W. L., Simpson, K., and Lord, J. (1971). Archives of Disease in Childhood, 46, 189. The response of low birthweight infants to treatment with folic acid. Folate deficiency, detected by measuring serum and red cell levels, was seen within a group of low birthweight infants who had been followed for a period of 9 months. A similar group treated with $14 \times 100 \mu \mathrm{g}$ folic acid by intramuscular injection over a period of 28 days during the first 5 weeks of life had significantly higher folate levels. There was no evidence of megaloblastic anaemia in the untreated group and no differences from the treated group in haemoglobin concentration or other haematological index except for a significant increase in neutrophils with 5-lobed nuclei at 3 months. We conclude that folate should be given from birth to all infants of low birthweight, but its form, and the route, dosage, and duration of treatment merit further investigation.
\end{abstract}

The folate status of term and premature infants has been studied by Matoth et al. (1964); Shojania and Gross (1964); Matoth, Pinkas, and Soroka (1965); Strelling et al. (1966); Vanier and Tyas (1966, 1967), and Roberts et al. (1969). All noted a fall in serum and red cell folate in early infancy, the fall being most rapid and profound in low birthweight and gestationally immature infants. Demands for folate are highest in this group presumably because of rapid growth, and some of these authors and Gray and Butler (1965) described megaloblastic anaemia responding to folic acid in premature babies.

The dietary folate requirements of newborn infants have been estimated to be $20-50 \mu \mathrm{g}$ daily, 10 times those of adults based on body weight (Matoth et al., 1964; Sullivan, Luhby, and Streiff, 1966). Hoffbrand (1970) suggested that prophylactic folic acid be given, for a few months after birth, to infants weighing less than $1.5 \mathrm{~kg}$ at birth and to debilitated infants who have had prolonged infections or repeated replacement transfusions. This communication reports the effect of prophylaxis with folic acid on the clinical and haematological status of low birthweight infants.

\footnotetext{
Received 2 October 1970.

$\star$ Present address: Biological Sciences Department, Paddington Technical College, W.2.
}

\section{Methods}

A group of 10 infants of low birthweight $(<1800 \mathrm{~g})$ were given folic acid. First a venous blood sample was collected within 5 days of birth; immediately afterwards the infants received $100 \mu \mathrm{g}$ folic acid by intramuscular injection. This dose was repeated on alternate days for 14 injections (a total of $1.4 \mathrm{mg}$ folic acid). Blood samples were taken on the 17th and 28th days of the investigation and then at 3,6 , and 9 months. The results were compared with those from a group of 20 similar but untreated infants. There was no evidence of anaemia in the mothers during their pregancy as judged by haemoglobin concentration, but it was difficult to establish which of the mothers had received folic acid.

All infants received feeds of the same evaporated milk. No additional vitamins or iron were given during the period of treatment. Their milk intake, body weight, and longitudinal growth were recorded during the first 5 weeks. Haemoglobin concentration $(\mathrm{Hb})$, packed cell volume (PCV), red blood cell count (RBC), mean corpuscular haemoglobin concentration (MCHC), mean corpuscular volume (MCV), reticulocyte count, and differential neutrophil count were record zd for each blood sample. The differential neutrophil counts were made by Schilling's method and the Cooke and Ponder modification of Arneth's classification (Wintrobe, 1967), in which 100 neutrophils in a peripheral blood film were counted and classified according to the number of lobes forming the nucleus. Serum vitamin B12 was assayed according to the method of Anderson (1964), serum folate as described by Waters and Mollin (1961) and red cell folate as des- 
TABLE I

Serum and Red Cell Folate Levels in Two Groups of Low Birthweight Infants. Treated Group Received $100 \mu \mathrm{g}$ Folic Acid i.m. on Alternate Days for 28 Days

\begin{tabular}{|c|c|c|c|c|c|c|c|c|c|c|}
\hline & \multicolumn{4}{|c|}{ Serum Folate $(\mathrm{ng} / \mathrm{ml})$} & \multirow{3}{*}{$\begin{array}{c}\text { Significant } \\
\text { Difference } \\
\text { Between } \\
\text { Treated and } \\
\text { Untreated } \\
\text { (Student's } \\
\text { t test) }\end{array}$} & \multicolumn{4}{|c|}{ Red Cell Folate (ng/ml) } & \multirow{3}{*}{$\begin{array}{c}\text { Significant } \\
\text { Difference } \\
\text { Between } \\
\text { Treated and } \\
\text { Untreated } \\
\text { (Student's } \\
\text { t test) }\end{array}$} \\
\hline & \multicolumn{2}{|c|}{ Treated } & \multicolumn{2}{|c|}{ Untreated } & & \multicolumn{2}{|c|}{ Treated } & \multicolumn{2}{|c|}{ Untreated } & \\
\hline & Mean & Range & Mean & Range & & Mean & Range & Mean & Range & \\
\hline $\begin{array}{l}\text { Pretreatment } \\
\text { After } 17 \text { days } \\
\text { After } 28 \text { days } \\
\text { Aged } 3 \text { months } \\
\text { Aged } 6 \text { months } \\
\text { Aged } 9 \text { months }\end{array}$ & $\begin{array}{l}15 \cdot 8 \\
26 \cdot 4 \\
19 \cdot 7 \\
10 \cdot 5 \\
13 \cdot 5 \\
18 \cdot 8\end{array}$ & $\begin{array}{c}6 \cdot 3-38 \cdot 8 \\
8 \cdot 2-80 \cdot 0 \\
4 \cdot 6-29 \cdot 8 \\
4 \cdot 7-14 \cdot 2^{\star} \\
4 \cdot 5-16 \cdot 6 \\
12 \cdot 3-24 \cdot 2\end{array}$ & $\begin{array}{r}26 \cdot 5 \\
4 \cdot 8 \\
4 \cdot 3 \\
5 \cdot 0 \\
10 \cdot 0 \\
10 \cdot 0\end{array}$ & $\begin{array}{c}5 \cdot 0-64 \cdot 0 \\
1 \cdot 5-9 \cdot 8^{\star} \\
1 \cdot 8-10 \cdot 2 \\
2 \cdot 5-6 \cdot 8 \\
5 \cdot 8-15 \cdot 3^{\star} \\
5 \cdot 3-13 \cdot 4\end{array}$ & $\begin{array}{l}P<\overline{0.001} \\
P<0.001 \\
P<0.025 \\
P<\overline{0.005}\end{array}$ & $\begin{array}{l}389 \\
357 \\
351 \\
273 \\
317 \\
444\end{array}$ & $\begin{array}{c}98-733 \\
182-540 \\
198-593 \\
161-418^{\star} \\
190-457 \\
270-631\end{array}$ & $\begin{array}{l}581 \\
341 \\
215 \\
159 \\
333 \\
381\end{array}$ & $\begin{array}{c}310-887 \\
186-715^{\star} \\
85-352^{\star} \\
61-292 \\
164-448^{\star} \\
92-650\end{array}$ & $\begin{array}{c}- \\
\mathbf{P}<\overline{0.005} \\
\mathbf{P}<0.01 \\
-\end{array}$ \\
\hline
\end{tabular}

$\star$ Values at these times were significantly different from those recorded in the preceding sample $(\mathrm{P}<0.001$ to $<0.025)$.

Normal levels in adults: serum folate $5-23 \mathrm{ng} / \mathrm{ml}$.

Red cell folate $160-640 \mathrm{ng} / \mathrm{ml}$ (from the same laboratory).

scribed by Hoffbrand, Newcombe, and Mollin (1966). Feeds were prepared by diluting 1 part of evaporated milk with $2 \frac{1}{2}$ parts of water. Assays for total folate and free folate activity were carried out on milk prepared for feeding, on 4 other makes of milk reconstituted, human milk (10th day), ana pasteurized cow's milk. Assays were carried out according to the method described by Butterworth, Santini, and Frommeyer (1963), with ascorbic acid added to the initial buffer used.

\section{Results}

Clinical. The group of infants treated with folic acid consisted of 5 males and 5 females with a mean birthweight of $1530 \mathrm{~g}$ (range 920 to $1790 \mathrm{~g}$ ). The mean gestational age at birth was 33 weeks (range 30 to 36 ). The untreated group comprised 11 males and 9 females, mean birthweight $1560 \mathrm{~g}$ (range 920 to $1870 \mathrm{~g}$ ), mean gestational age 33 weeks (range 26 to 40 ). The milk intake, gain in body weight, and longitudinal growth were each not significantly different for the two groups.

Serum and red cell folate levels. Serum and red cell folate levels in the two groups of infants are shown in Table I and the Fig.

After 17 days there was a very significant fall in the serum folate level in untreated infants $(P<0.001)$. There was no further significant fall at 28 days and 3 months, but there was a significant rise at 6 months $(P<0.001)$. In the treated group the levels of folate in the serum at 17 and 28 days were not different from those before treatment began. At 3 months, there had been a significant fall $(P<0.02)$ but the mean level was within the range of normal values in adults and the lowest level recorded in the group was $4 \cdot 7 \mathrm{ng} / \mathrm{ml}$.
There was a very significant fall in red cell folate in untreated infants after 17 days $(P<0.001)$ and a further significant fall by 28 days $(P<0.005)$. The fall of folate in the red cell was more prolonged than that in the serum, but a significant rise occurred at 6 months parallelling the rise in the serum level. In the treated group there was no significant difference in the red cell folate at 17 days and 28 days nor between these levels and those at the start of the investigation. There was however a significant fall at 3 months compared with previous levels $(P<0.02)$ followed by a rise parallel with that seen in the serum folate.

Comparing the treated and untreated groups there was a very significant difference in serum folate level at 17 and 28 days (both $P<0 \cdot 001$ ). The differences between the two groups at 3 and 9 months were significant $(P<0.025 ; P<0.05)$. Differences in red cell folate were only significant at 28 days $(P<0.005)$ and 3 months $(P<0.01)$. There were no differences in red cell folate between the two groups at 17 days, due to the higher levels in the initial samples from untreated infants.

Serum vitamin B12 levels. There was a pronounced fall in the serum vitamin B12 levels in both groups during the first 4 weeks (Table II) but the levels rose again at 3 months. There were no significant differences between the groups at any time during the study. Low borderline levels of serum vitamin B12 were seen in individual infants in the treated group. One infant had $90 \mathrm{pg} / \mathrm{ml}$ before treatment, 2 had $92 \mathrm{pg} / \mathrm{ml}$ at 17 days, 3 had levels of 80,110 , and $115 \mathrm{pg} / \mathrm{ml}$ at 28 days, and $1 \mathrm{had} 110 \mathrm{pg} / \mathrm{ml}$ at 3 months. None of these showed evidence of megaloblastic anaemia though 


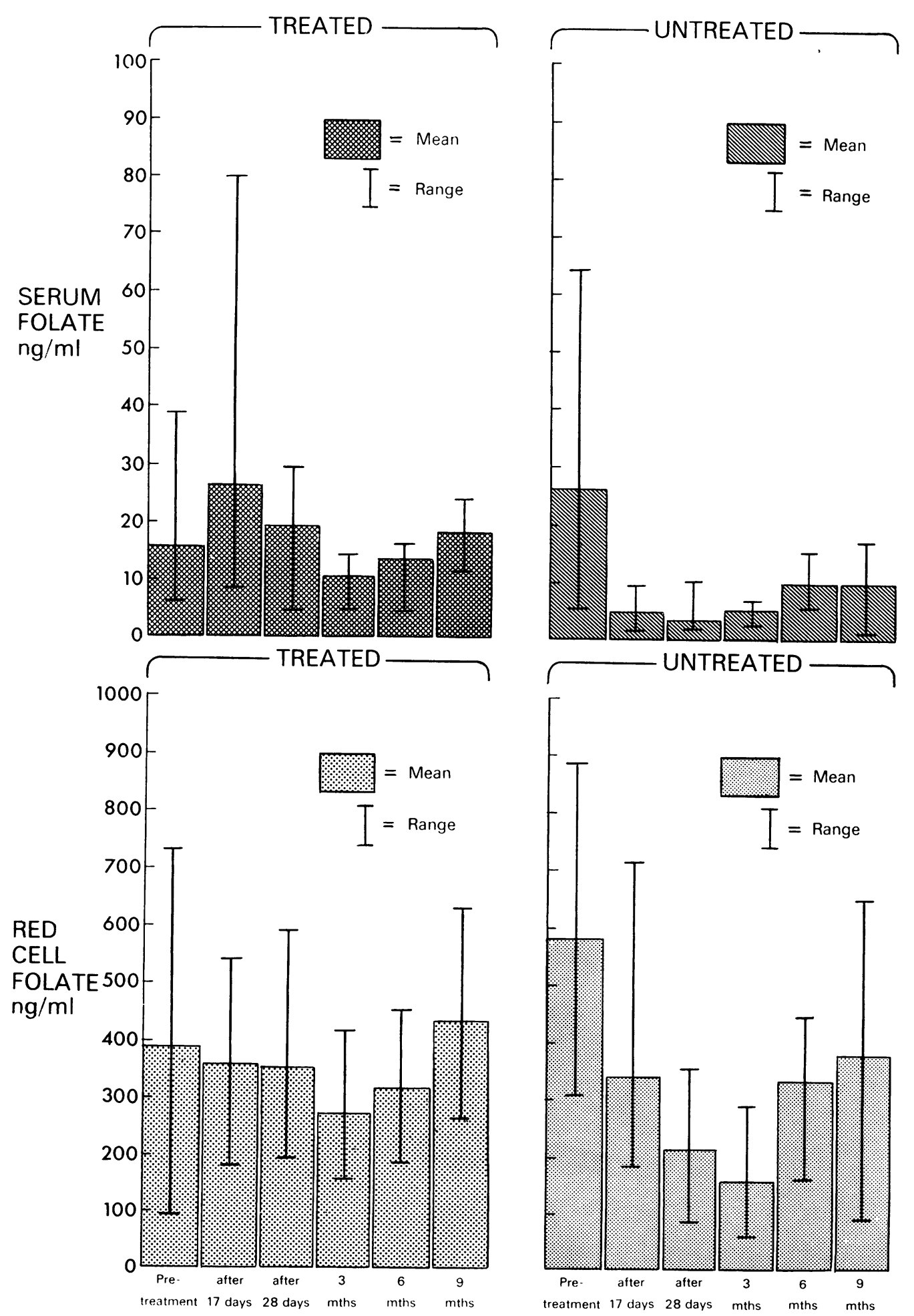

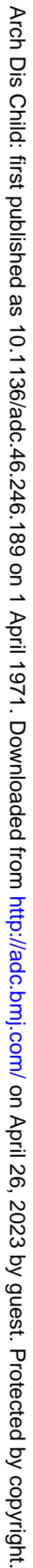


TABLE II

Serum B12 Levels in Two Groups of Low Birthweight Infants (Treated Group Received $100 \mu \mathrm{g}$ Folic Acid i.m. on Alternate Days for 28 Days)

\begin{tabular}{|c|c|c|c|c|}
\hline & \multicolumn{4}{|c|}{ Serum B12 $(\mathrm{pg} / \mathrm{ml})$} \\
\hline & \multicolumn{2}{|c|}{ Treated } & \multicolumn{2}{|c|}{ Untreated } \\
\hline $\begin{array}{l}\text { Pretreatment } \\
\text { At } 17 \mathrm{dy} \\
\text { At } 28 \mathrm{dy} \\
\text { At } 3 \mathrm{mth} \\
\text { At } 6 \mathrm{mth} \\
\text { At } 9 \mathrm{mth}\end{array}$ & $\begin{array}{l}270 \\
195 \\
151 \\
260 \\
401 \\
361\end{array}$ & $\begin{array}{r}90-560 \\
92-345 \\
80-230 \\
110-415 \\
235-550 \\
230-600\end{array}$ & $\begin{array}{l}357 \\
220 \\
199 \\
359 \\
497 \\
585\end{array}$ & $\begin{array}{l}140-640 \\
135-330 \\
120-235 \\
170-630 \\
330-825 \\
290-1120\end{array}$ \\
\hline
\end{tabular}

Normal levels in adults (from the same laboratory) 120-925 $\mathrm{pg} / \mathrm{ml}$. $\quad 80-120 \mathrm{pg} / \mathrm{ml}$ is considered 'borderline'.

low levels were found consecutively in 3 infants. All these infants had serum and red cell folates within the normal range.

Haematological findings. $\mathrm{Hb}(\mathrm{g} / 100 \mathrm{ml})$ and RBC are shown in Table III. There was no difference in these, between the groups, nor were any differences seen in PCV, MCV, MCHC, and reticulocyte count. The results of differential neutrophil counts in the treated group and in 10 of the untreated group showed that there was a tendency throughout, except at 6 months, for untreated infants to have more neutrophils with 3 or 4 lobes. This was reflected in the figures for mean lobe counts shown in Table IV. There were no significant differences in the mean lobe counts between the groups however. Neutrophils with 5 lobes were only seen in significantly greater numbers in the untreated group at 3 months when folate levels were at their lowest. $8 \cdot 3 \%$ of cells in untreated infants had 5 lobes at 3 months as opposed to $<1 \%$ in treated infants $(P<0.05)$. Two infants in the untreated group having neutrophils with 5 lobes showed mean lobe counts greater than the upper limit of the mean counts in treated infants. Neutrophils with 5 lobes were found in only one infant in the treated group in the presence of a low serum $B 12(110 \mathrm{pg} / \mathrm{ml}$ at 3 months).

\section{TABLE III}

Haemoglobin Concentration and Red Cell Counts in Two Groups of Low Birthweight Infants

\begin{tabular}{|c|c|c|c|c|c|c|c|c|c|c|}
\hline & & & \multicolumn{4}{|c|}{ Hb Concentration $(\mathrm{g} / 100 \mathrm{ml})$} & \multicolumn{4}{|c|}{ Red Cell Count $\left(\times 10^{6} / \mathrm{mm}^{3}\right)$} \\
\hline & & & \multicolumn{2}{|c|}{ Treated } & \multicolumn{2}{|c|}{ Untreated } & \multicolumn{2}{|c|}{ Treated } & \multicolumn{2}{|c|}{ Untreated } \\
\hline & & & Mean & Range & Mean & Range & Mean & Range & Mean & Range \\
\hline $\begin{array}{l}\text { Pretreatment } \\
\text { At } 17 \text { days } \\
\text { At } 28 \text { days } \\
\text { At } 3 \text { months } \\
\text { At } 6 \text { months } \\
\text { At } 9 \text { months }\end{array}$ & $\begin{array}{l}\ldots \\
\cdots \\
\ldots \\
\ldots \\
\ldots\end{array}$ & $\begin{array}{l}\cdots \\
\cdots \\
\cdots \\
\cdots \\
\cdots\end{array}$ & $\begin{array}{r}16 \cdot 7 \\
12 \cdot 3 \\
9 \cdot 8 \\
11 \cdot 0 \\
11 \cdot 4 \\
10 \cdot 5\end{array}$ & $\begin{array}{r}14 \cdot 1-18 \cdot 7 \\
9 \cdot 9-15 \cdot 7 \\
8 \cdot 2-13 \cdot 3 \\
9 \cdot 1-14 \cdot 7 \\
9 \cdot 7-13 \cdot 2 \\
8 \cdot 9-11 \cdot 5\end{array}$ & $\begin{array}{r}16 \cdot 3 \\
11 \cdot 6 \\
9 \cdot 3 \\
10 \cdot 4 \\
10 \cdot 9 \\
11 \cdot 6\end{array}$ & $\begin{array}{r}12 \cdot 3-20 \cdot 7 \\
8 \cdot 9-13 \cdot 5 \\
7 \cdot 3-13 \cdot 3 \\
8 \cdot 6-11 \cdot 5 \\
8 \cdot 3-12 \cdot 4 \\
9 \cdot 9-13 \cdot 2\end{array}$ & $\begin{array}{l}4 \cdot 3 \\
3 \cdot 4 \\
3 \cdot 0 \\
3 \cdot 4 \\
4 \cdot 6 \\
4 \cdot 4\end{array}$ & $\begin{array}{l}3 \cdot 6-5 \cdot 0 \\
2 \cdot 8-4 \cdot 2 \\
2 \cdot 5-3 \cdot 2 \\
3 \cdot 1-3 \cdot 7 \\
4 \cdot 2-5 \cdot 3 \\
4 \cdot 1-4 \cdot 9\end{array}$ & $\begin{array}{l}4 \cdot 5 \\
3 \cdot 3 \\
2 \cdot 9 \\
3 \cdot 5 \\
4 \cdot 3 \\
4 \cdot 6\end{array}$ & $\begin{array}{l}3 \cdot 5-4 \cdot 8 \\
2 \cdot 6-4 \cdot 1 \\
2 \cdot 1-3 \cdot 8 \\
2 \cdot 7-4 \cdot 2 \\
3 \cdot 4-5 \cdot 0 \\
4 \cdot 0-5 \cdot 6\end{array}$ \\
\hline
\end{tabular}

TABLE IV

Neutrophil Lobe Count in Two Groups of Low Birthweight Infants (figures for untreated infants represent 10 infants investigated and figures for serum and red cell folate are shown because they do not compare with those shown in Table I which represents results in 20 infants)

\begin{tabular}{|c|c|c|c|c|c|c|c|c|c|c|}
\hline & & & & Treated & & & & Untreated & & \\
\hline & & & $\begin{array}{l}\text { Mean } \\
\text { Lobe } \\
\text { Count }\end{array}$ & $\begin{array}{l}\% \text { Cells } \\
\text { with } \\
4 \text { Lobes }\end{array}$ & $\begin{array}{l}\% \text { Cells } \\
\text { with } \\
5 \text { Lobes }\end{array}$ & $\begin{array}{l}\text { Mean } \\
\text { Lobe } \\
\text { Count }\end{array}$ & $\begin{array}{l}\% \text { Cells } \\
\text { with } \\
4 \text { Lobes }\end{array}$ & $\begin{array}{l}\% \text { Cells } \\
\text { with } \\
5 \text { Lobes }\end{array}$ & $\begin{array}{c}\text { Mean Serum } \\
\text { Folate } \\
(\mathrm{ng} / \mathrm{ml})\end{array}$ & $\begin{array}{c}\text { Mean Red } \\
\text { Cell Folate } \\
(\mathrm{ng} / \mathrm{ml})\end{array}$ \\
\hline $\begin{array}{l}\text { Pretreatment } \\
\text { At } 17 \text { days } \\
\text { At } 28 \text { days } \\
\text { At } 3 \text { months } \\
\text { At } 6 \text { months } \\
\text { At } 9 \text { months }\end{array}$ & $\begin{array}{l}\ldots \\
\cdots \\
\cdots \\
\cdots \\
\cdots\end{array}$ & $\begin{array}{l}\ldots \\
\cdots \\
\cdots \\
\cdots \\
\cdots \\
\cdots\end{array}$ & $\begin{array}{l}1 \cdot 8 \\
1 \cdot 9 \\
1 \cdot 9 \\
2 \cdot 0 \\
2 \cdot 2 \\
2 \cdot 1\end{array}$ & $\begin{array}{l}2 \cdot 4 \\
2 \cdot 2 \\
2 \cdot 3 \\
3 \cdot 25 \\
4 \cdot 75 \\
3 \cdot 8\end{array}$ & $\begin{array}{l}<1 \\
<1 \\
<1 \\
<1 \star \\
<1 \\
<1\end{array}$ & $\begin{array}{l}1 \cdot 8 \\
2 \cdot 3 \\
2 \cdot 1 \\
2 \cdot 5 \\
2 \cdot 1 \\
2 \cdot 3\end{array}$ & $\begin{array}{r}1 \cdot 5 \\
10 \cdot 0 \\
12 \cdot 5 \\
8 \cdot 0 \\
2 \cdot 0 \\
8 \cdot 0\end{array}$ & $\begin{array}{l}<1 \\
1 \cdot 14 \\
<1 \\
\quad 8 \cdot 33^{\star} \\
<1 \\
<1\end{array}$ & $\begin{array}{r}24 \cdot 7 \\
5 \cdot 2 \\
4 \cdot 4 \\
5 \cdot 4 \\
7 \cdot 4 \\
12 \cdot 2\end{array}$ & $\begin{array}{l}560 \\
365 \\
233 \\
171 \\
328 \\
396\end{array}$ \\
\hline
\end{tabular}

$\star$ Significant $(\mathrm{P}<0.05)$. 
Discussion

This investigation has confirmed the pattern previously described in low birthweight infants, namely a rapid fall of serum folate and a slower fall of red cell folate. Low levels of serum folate were found sooner in life in this study than in that by Roberts et al. (1969), but the lowest recorded at 3 months here $(2.5 \mathrm{ng} / \mathrm{ml})$ was not as low as recorded by those authors $(0.6 \mathrm{ng} / \mathrm{ml})$. Neither birthweight nor gestational age could be correlated with initial serum or red cell folate in either of the groups studied here.

In our study it has been shown that a total of $1.4 \mathrm{mg}$ folic acid injected intramuscularly over a period of 4 weeks was sufficient to increase significantly serum and red cell folate compared with untreated infants and to maintain them at normal levels for 9 months. At 3 months, 5 of the 20 untreated infants had a subnormal red cell folate, though no infant showed evidence of megaloblastic anaemia or an unduly low haemoglobin concentration. A greater number of neutrophils with 5 lobes were seen in the untreated group at 3 months. Hypersegmentation of neutrophils (a shift to the right) is characteristically seen in vitamin B12 or folate deficiency and the findings might therefore suggest subclinical folate deficiency.

The results of folate assays of milks are shown in Table V. It appears by calculation and from the results that the infants in our study did not receive sufficient folate from their diet. For example, an infant weighing $1400 \mathrm{~g}$ at birth received at the age of 1 week $200 \mathrm{ml}$ milk daily containing 13.6 $\mu \mathrm{g}$ total folate $(10.6 \mu \mathrm{g}$ free folate) and at 5 weeks $600 \mathrm{ml}$ daily containing $40.8 \mu \mathrm{g}(31.8 \mu \mathrm{g})$. Even if absorption and utilization were complete this amount is unlikely to be adequate. Free folate is immediately available to the infant but other folates are in the

\section{TABLE V}

Folate Activity in Evaporated Milk Feeds Given to Two Groups of Infants (results of assays for 4 other proprietary milk foods, prepared according to manufacturer's instructions, human milk, and pasteurized cow's milk are also reported)

\begin{tabular}{l|c|c}
\hline \multicolumn{1}{c|}{ Feed } & $\begin{array}{c}\text { Total Folate } \\
(\mu \mathrm{g} / 1 .)\end{array}$ & $\begin{array}{c}\text { Free Folate } \\
(\mu \mathrm{g} / 1 .)\end{array}$ \\
\hline Evaporated milk & $68 \cdot 0$ & $53 \cdot 0$ \\
Milk A & $35 \cdot 2$ & $19 \cdot 4$ \\
Milk B & $73 \cdot 6$ & $64 \cdot 0$ \\
Milk C & $55 \cdot 2$ & $51 \cdot 6$ \\
Milk D & $51 \cdot 6$ & $51 \cdot 2$ \\
Human milk & $64 \cdot 0$ & 32.0 \\
Pasteurized cow's milk & $60 \cdot 0$ & $58 \cdot 0$ \\
\hline
\end{tabular}

form of polyglutamates and require the action of intestinal mucosal enzymes before being available for absorption. Since the activity of intestinal pteroylpolyglutamate hydrolase in the premature infant is unknown the deficit may be larger. The folate activities of the milks examined were similar to those found by Ford and Scott (1968), and no other milk would have provided significantly more folate to the infant than that used to feed the infants in our investigation.

Hussain and Wadsworth (1968) found a reduced concentration of liver folate in infants of $<37$ weeks gestation who weighed $<2.5 \mathrm{~kg}$ and died in the perinatal period. It appears therefore that low birthweight infants become deficient in folate very soon after birth because of an inadequate dietary intake in the presence of insufficient reserves.

Folate derivatives are important in the biosynthesis of DNA precursors, and deficiency may produce arrest or disrupticn of DNA synthesis (Menzies et al., 1966). Protein synthesis may be limited through the failure of amino acid biosynthesis, which may also restrict formation of essential enzymes and interfere with cell growth (Blakely, 1969). Fetal development in the rat is known to be adversely affected by folate deficiency (Nelson et al., 1955, 1956), and the human fetus is very sensitive to folate antagonists such as aminopterin (Thiersch, 1952). These data suggest that infants especially those who are of low birthweight or gestationally immature, should be ensured an adequate folate intake. There was no evidence of enhanced weight gain or longitudinal growth in the group of infants treated with folic acid when these were measured accurately during 5 weeks after birth. If the untreated group were so depleted of folate that growth was affected, it was not significantly apparent by 5 weeks. An effect might have been expected at 3 months when the results suggested that the nadir for folate status had been reached in our infants. Unfortunately it was not possible to measure growth accurately at that time, but no obvious differences in the groups were apparent.

Although overt deficiency did not occur in the untreated group in the study, our findings suggest that low birthweight infants require prophylactic folate in the early months to prevent depletion and subclinical folate deficiency. If other stresses such as infection were to be present in the untreated infant severe deficiency and megaloblastic anaemia might ensue. Hoffbrand (1970) suggested that infants weighing less than $1500 \mathrm{~g}$ at birth should be treated. However Strelling et al. (1966) found megaloblastic 
changes in buffy coat preparations in 3 of 18 infants weighing $1500-1800 \mathrm{~g}$ at birth. We included infants weighing up to $1870 \mathrm{~g}$ in our study, and it might be argued that those weighing up to $2000 \mathrm{~g}$ should receive additional folate. The method of administration of folic acid chosen for this investigation was not entirely convenient and it remains to be seen whether oral administration of folic acid for a similar short period would be as effective. Further investigation is required to establish the best form and mode of administration of folate to young infants.

We thank the medical, nursing, and laboratory staff at Leicester General Hospital, and Professor D. L. Mollin, Dr. Barbara Anderson, Dr. Jean Cowan, and their colleagues of the Haematology Department, St. Bartholomew's Hospital, London E.C.1, for advice and assays of serum B12 and folate.

\section{REFERENCES}

Anderson, B. B. (1964). Investigations into the Euglena method for the assay of the vitamin B12 in serum. Fournal of Clinical Pathology, 17, 14.

Blakely, R. L. (1969). The biochemistry of folic acid and related pteridines. Frontiers of Biology, 13, p. 391. Edited by A. Neuberger and E. L. Tatum. N. Holland, Amsterdam and London.

Butterworth, C. E., Jr., Santini, R., Jr., and Frommeyer, W. B. Jr. (1963). The pteroylglutamate components of American diets as determined by chromatographic fractionation. Fournal of Clinical Investigation, 42, 1929.

Ford, J. E., and Scott, K. J. (1968). The folic acid activity of some milk foods for babies. Fournal of Dairy Research, 35, 85.

Gray, O. P., and Butler, E. B. (1965). Megaloblastic anaemia in premature infants. Archives of Disease in Childhood, 40, 53

Hoffbrand, A. V. (1970). Folate deficiency in premature babies. Archives of Disease in Childhood, 45, 441.

Hoffbrand, A. V., Newcombe, B. F., and Mollin, D. L. (1966). Method of assay of red cell folate activity and the value of the assay as a test for folate deficiency. Fournal of Clinical Patho$\log y, 19,17$.
Hussain, M. A., and Wadsworth, G. R. (1968). Liver folate of infants dying in the perinatal period. Proceedings of the Nutrition Society, 27, 7A.

Matoth, Y., Pinkas, A., Zamir, R., Mooallem, F, and Grossowicz, N. (1964). Studies on folic acid in infancy. I. Blood levels of folic and folinic acid in healthy infants. Pediatrics, 33, 507.

Matoth, Y., Pinkas, A.., and Soroka, C. (1965). Folate in artificially fed and breast-fed infants and in lactating mothers. (Abstr.). Israel fournal of Medical Sciences, 1, 730.

Menzies, R. C., Crossen, P. E., Fitzgerald, P. H., and Grinz, F. W. (1966). Cytogenic and cytochemical studies on marrow cells in B12 and folate deficiency. Blood, 28, 581 .

Nelson, M. M., Wright, H. V., Asling, C. W., and Evans, H. M. (1955). Multiple congenital abnormalities resulting from transitory deficiency of pteroylglutamic acid during gestation in the rat. Fournal of Nutrition, 56, 349.

Nelson, M. M., Wright, H. V., Baird, C. D. C., and Evans, H. M. (1956). Effect of 36-hour period pteroyglutamic acid deficiency of fetal development in the rat. Proceedings of the Society for Experimental Biology and Medicine, 92, 554.

Roberts, P. M., Arrowsmith, D. E., Rau, S. M., and Monk-Jones, M. E. (1969). Folate state of premature infants. Archives of Disease in Childhood, 44, 637.

Shojania, A. M., and Gross, S. (1964). Folic acid deficiency and prematurity. Fournal of Pediatrics, 64, 323.

Strelling, M. K., Blackledge, G. D., Goodall, H. B., and Walker, C. H. M. (1966). Megaloblastic anaemia and whole-blood folate levels in premature infants. Lancet, 1, 898.

Sullivan, L. W., Luhby, A. L., and Streiff, R. R. (1966). Studies of the daily requirement for folic acid in infants and the etiology of folate deficiency in goat's milk megaloblastic anemia. (Abstr.) American fournal of Clinical Nutrition, 18, 311.

Thiersch, J. B. (1952). Therapeutic abortion with folic acid antagonistic 4-aminopteroylglutamic acid (4-amino p.G.A.) administered by the oral route. American fournal of Obstetrics and Gynecology, 63, 1298.

Vanier, T. M., and Tyas, J. F. (1966). Folic acid status in normal infants during the first year of life. Archives of Disease in Childhood, 41, 658.

Vanier, T. M., and Tyas, J. F. (1967). Folic acid status in premature infants. Archives of Disease in Childhood, 42, 57.

Waters, A. H., and Mollin, D. L. (1961). Studies on the folic acid activity of human serum. Fournal of Clinical Pathology, 14, 335.

Wintrobe, M. M. (1967). Clinical Hematology, p. 263. Kimpton, London.

Correspondence to: Dr. W. L. Burland, Clinical Investigation Unit, Glaxo Laboratories, Greenford, Middlesex. 